ISSN:2656-4270 (Online) 1410-4466 (Print) Accredited by Ministry of Research, Technology, and Higher Education with the ranking of Sinta (S4) SK NO.28/E/KPT/2019, 26th September 2019
Buletin Penelitian Sosial Ekonomi Pertanian Fakultas Pertanian Universitas Haluoleo

2020:22(2):66-71

http://ojs.uho.ac.id/index.php/sosek

doi: http://dx.doi.org/10.37149/sosek.v22i2.13874

\title{
FERTILIZATION EFFECTIVENESS ON THE PRODUCTIVITY OF FRESH FRUIT BUNCHES AND MAINTENANCE COSTS OF OIL PALM
}

\author{
Wandha Atmaka $\mathrm{Aji}^{{ }^{1 *}}$, Aditya Dyah Utami ${ }^{1)}$, Bagus Nugroho ${ }^{1)}$, Toyyibah ${ }^{1)}$, \\ Mukti Ahmad Nurcahyo" \\ ${ }^{1}$ Akademi Komunitas Perkebunan Yogyakarta \\ *Corresponding author : wandha.aji@gmail.com
}

To cite this article:

Aji, W., Utami, A., Nugroho, B., Toyyibah, T., \& Nurcahyo, M. (2021). Fertilization Effectiveness Towards the Productivity of Fresh Fruit Bunches and Maintenance Costs of Palm Oil. Buletin Penelitian Sosial Ekonomi Pertanian Fakultas Pertanian Universitas Haluoleo, 22(2), 66 - 71. doi:http://dx.doi.org/10.37149/bpsosek.v22i2.13874

Received: August 31, 2020; Accepted: January 24, 2020; Published: January 28, 2020

\section{ABSTRACT}

The productivity of oil palm is highly dependent on the application of fertilization. Fertilizer applications must pay attention to its effectiveness and efficiency so that nutrients are absorbed optimally at the right time and right dosage. This research was conducted to assess the effectiveness of fertilization time. In addition, this also aimed to examine the effectiveness of oil palm fertilization which affects the productivity of fresh fruit bunches (FFB) and increases the production income. The data used were secondary data including fertilization and productivity of FFB at time intervals after fertilization for 6, 7, and 8 months in Kujan Estate Division, PT Menthobi Makmur Lestari (MMaL), Kujan Village, Nanga Bulik District, Lamandau, Central Kalimantan Province. The data obtained were analyzed using MS software. Excel was also employed to describe the dosage and time applied for 1 year and the productivity of FFB after 6 months of fertilization. Fertilizer application in months with high rainfall and long dry season is less effective and efficient for nutrient availability. The productivity of FFB in the second semester after 6 months of fertilization has increased compared to the first semester. The effective application of fertilizers can increase the production of CPO and reduce the total maintenance cost of the oil palm company.

Keywords: crude palm oil; effectiveness of fertilization; fresh fruit bunches; legume cover crop; nutrients

\section{INTRODUCTION}

Oil palm plantations have bright prospects to be developed as a source of foreign exchange, expansion of employment opportunities, preservation of natural resources, and a mean for development (Ariyanti et al., 2019). Palm oil (Crude Palm Oil/CPO) with bright marketing prospects and competitive prices have caused more CPO demand (Wulandari \& Hernawati, 2017). Indonesia's CPO exports reached 1,791,774.29 tonnes with a value of USD 1,776,617.53 (Ministry of Agriculture 2019).

The productivity that has been achieved by oil palm plantations in Indonesia at this time must be continuously improved and maintained well such as in cultivation activities (Boafo et al., 2020). One of the activities in cultivation that requires management is fertilization (Tounkara et al., 2020). Fertilizing oil palm is commonly done manually and utilizes technology such as aircraft. Effective and efficient fertilization methods are able to improve oil palm growth (Cui et al., 2020). The right dosage also affects the growth and production (Setyawan et al., 2020). This also will cause the area, thickness, and chlorophyll content of leaves optimal (Emmanuel et al., 2020). If vegetative growth is good, generative development is also good, one of which is the productivity of oil palm FFB. When FFB increases, the CPO produced will also be higher (Moreno-Sader et al., 2020).

Oil palm fertilization is very dependent on the environment, especially rainwater. The high rainfall causes the fertilizer applied easily carried away by the water flow. As a result, fertilizers are not absorbed optimally (Cui et al., 2020). Ineffective fertilization will cause high operational costs for 
the company (Tröster et al., 2019). Therefore, it is important to pay attention to fertilization time, because the effectiveness of fertilization also affects the production costs incurred by the plantation. The more effective the fertilization, the more optimal the FFB produced, thus the production costs can be reduced and the income from the FFB sale will increase. Research on the effectiveness of fertilization on oil palm productivity has been carried out. However, there has not been any further study regarding the cost-effectiveness incurred by the plantation. Based on this, current study was conducted to assess the effectiveness of fertilization time. In addition, another objective was to assess the dosage that affects FFB productivity. This research further expects to find out how to increase FFB productivity and the sustainability of oil palm cultivation as well as increase the production income.

\section{MATERIALS AND METHODS}

This research was carried out in Block D-09 oil palm plantation with an area of 25 ha in Division 1 of Kujan Estate, PT Menthobi Makmur Lestari (MMaL), Kujan Village, Nanga Bulik District, Lamandau, Central Kalimantan Province. The data used were secondary data including the fertilization dosage and FFB productivity after 6 months of fertilization in the first and second semesters. The data obtained were analyzed using MS software, while excel was also employed to describe the dosage and time applied for 1 year and the productivity of FFB after 6 months of fertilization.

\section{RESULTS AND DISCUSSION}

Fertilization is very important in crop cultivation, especially oil palm because it increases the availability of nutrients (Emmanuel et al., 2020). Nutrients are needed for vegetative and generative growth (Ginting et al., 2018). Oil palm fertilization was carried out every month continuously, especially during the vegetative phase (Figure 1). The effectiveness of fertilizer absorption by plants is influenced by various factors, one of which is water availability. Therefore, when applying fertilizer, it is necessary to pay attention to the time of fertilization so that appropriate dosage can be determined and it can be absorbed properly (Njoroge et al., 2019; Chiamaka et al., 2020).

Figure 1 shows that the fertilizer dosage in March is the lowest compared to other months. The rainfall in March is quite high, ranging from $>300-350 \mathrm{~mm} /$ day. The high rainfall causes fertilizers to wash easily so that the nutrients absorbed by oil palm roots are not optimal (Siallagan et al., 2014). When the application of fertilizers is excessive, then it will not be effectively absorbed by plants (Rasool et al., 2020). It is because the nutrients are not bound by soil particles and are not available to plants. Therefore, plant growth and development are disrupted. Fertilization was not done in May and June because of the dry season at that time, while September was a long summer. Fertilization in the dry season is feared to burn the root tips of plants. Damage to plant tissue will reduce metabolism and have an impact on productivity (Akinnifesi et al., 2008).

The highest dosage was found in April, July, and October, which was 0.20 ton/ha. Currently, the weather conditions cannot be predicted certainly meaning that it is uncertain whether the month enters rainy season or dry season. However, when this research was carried out, April was entering the end of rainy season so that the fertilizer dosage used was added and became 0.20 tons/ha. Rainfall that is not too extreme with $<300 \mathrm{~mm} /$ day is a highly desired rainfall by an oil palm plantation company so that the application of fertilizer with a dosage of 0.20 tonnes/ha is expected to be optimally absorbed by the roots of oil palm. Then, July is the month when the fertilizer was applied the most and entering the dry season. The application in July was intended to determine the production so that fertilization effectiveness can be seen on the productivity of fresh oil palm fruit bunches during dry season fertilization (Darko et al., 2020).

October enters the rainy season, thus good fertilization is either carried out at the end of the dry season or the beginning of the rainy season. Therefore, through the fertilizer application of 0.20 tonnes/ha dosage, the effectiveness of fertilization and its production can be seen. Fertilization was not done in May and June because of the dry season, while September is a long summer. Fertilization in the dry season is feared to burn the root tips of plants because damage to plant tissue will decrease metabolism and affect the productivity. 


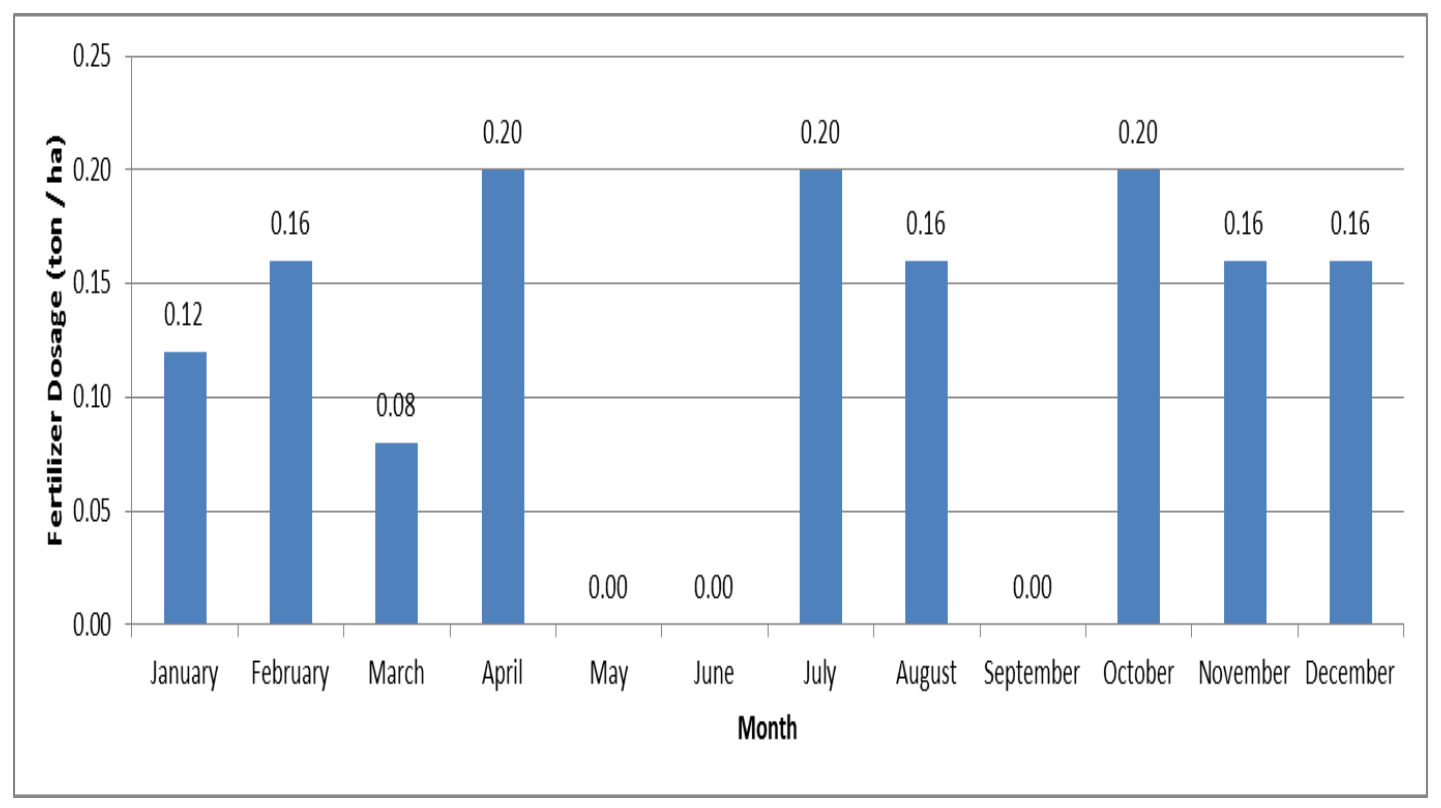

Figure 1. Fertilization dose

Optimal fertilization will affect the productivity of oil palm FFB. Figure 2 shows FFB productivity in the $1^{\text {st }}$ semester (June to November) after 6 months of fertilization. The productivity of FFB has fluctuated from June to November. The lowest FFB productivity was in July at 0.55 tons/ha, while the highest productivity was in October at 1.40 tons/ha. July was the slowest month because it is a dry month so it affects the fertilizer absorption.

The productivity of FFB from July to October increased while its productivity in November decreased to 0.62 ton/ha (Figure 2). The decrease of FFB in November was due to high rainfall. High rainfall will cause the flowers to be disrupted in the pollination process because the insect pollinating oil palm flowers, Elaeidobius kamerunicus, reduces pollination activity during the rainy season (Youse et al., 2020).

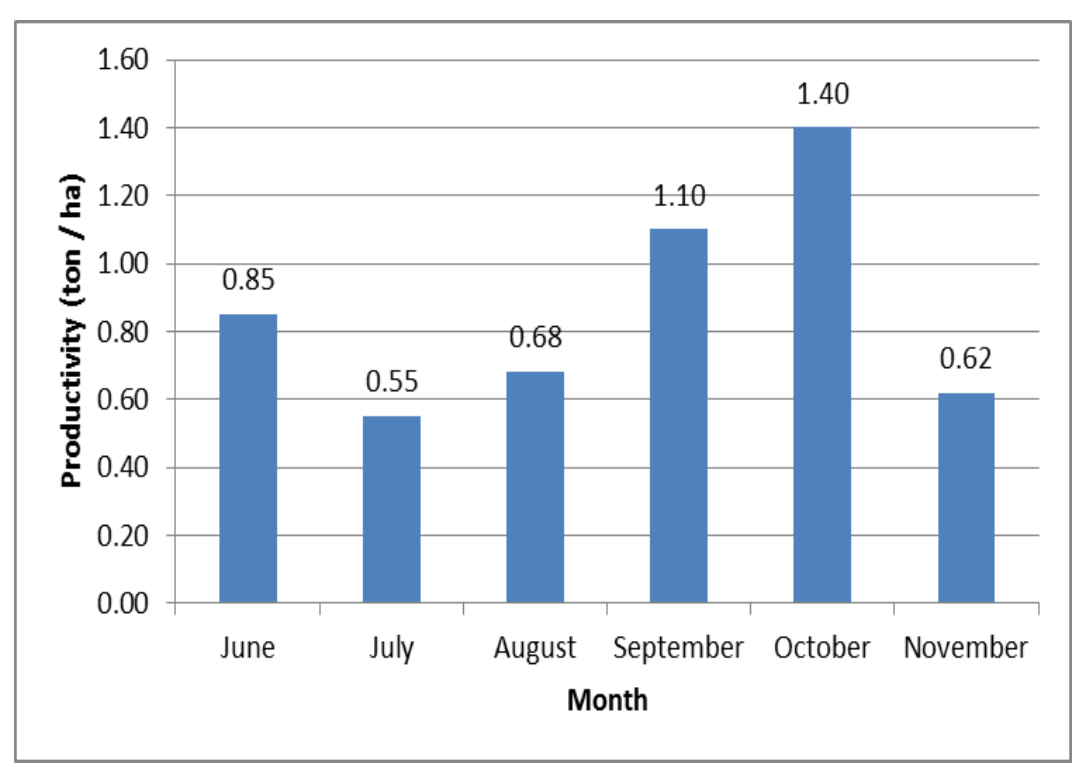

Figure 2. FFB productivity in semester 1 after 6 months of fertilization

The main productivity of oil palm is FFB. FFB is the result of generative growth of plants. Oil palm FFB correlates with the CPO produced. When the productivity of FFB increases, then CPO also increases. This is because the nutrient content which is important in conception is fulfilled (Siallagan et al., 2014). 


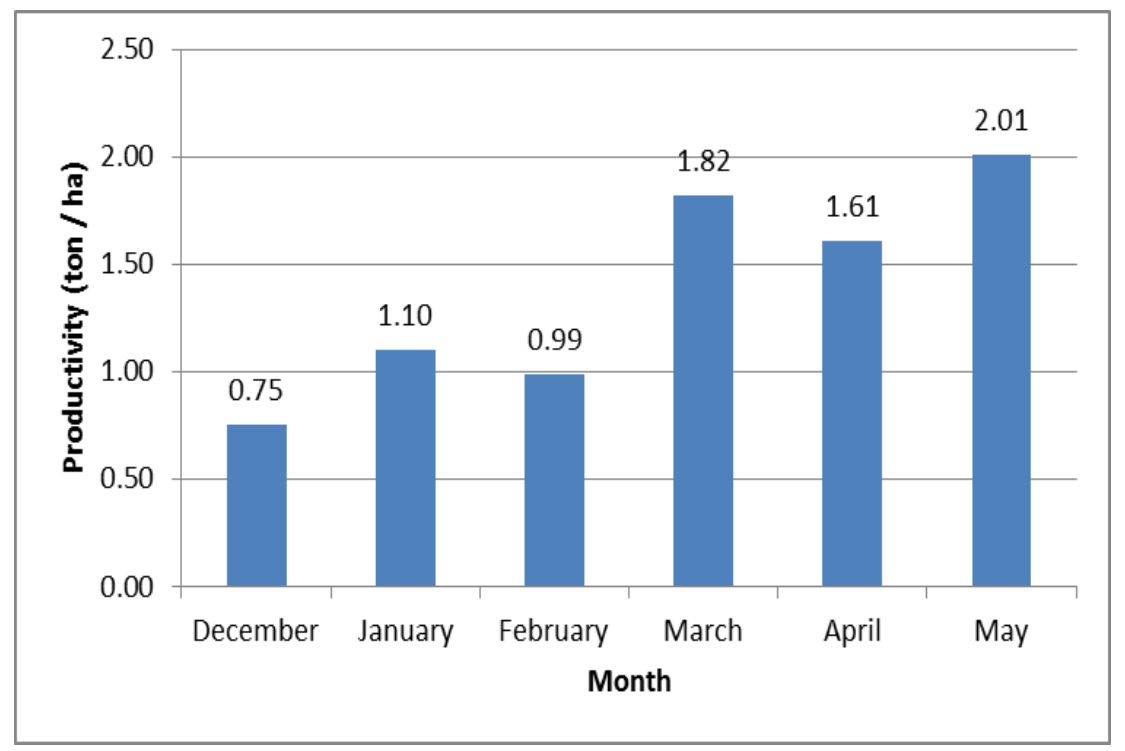

Figure 3. FFB productivity in semester 2 after 6 months of fertilization

The absorption of nutrients from the applied fertilizers will be more optimal after a certain time. The longer the time interval, the more increase the nutrient uptake by plants. As a result, optimal vegetative growth resulting in optimal flower formation. If the formation of flowers is optimal, the resulting fruit will also increase (Zhang et al., 2020). This is in accordance with Figure 3 which shows that the productivity of FFB in the second semester has increased compared to the first semester (Figure 2) ranging from $0.75-2.01$ tonnes/ha. However, FFB productivity from December to February was lower, namely $0.75-1.10$ tonnes/ha compared to March to May (1.61-2.01 tonnes/ha). This fluctuation is the same as the first semester, which is influenced by wet months and dry months.

The use of good fertilizers aims to make it easier for plants to absorb nutrients in the soil if the soil does not have legume cover crop (LCC) cover (Ball et al., 2020). The function of LCC was to maintain soil moisture, suppress weed growth, and provide $\mathrm{N}$ in the soil (Otto et al., 2020). If the area is already covered by LCC, it can reduce the use of fertilizers. This does not mean that the areas that have been covered by LCC are not fertilized. LCC only helps to reduce fertilizer use so that it can reduce the budget for relatively large fertilizer costs (Rodriguez et al., 2020).

The productivity of oil palm FFB correlates with the CPO produced. The more the amount of FFB increases, the more increase the amount of CPO yield (Devani, 2014). In CPO production, it seeks to optimize yield and improve product quality (Siallagan et al., 2014). The more optimal CPO is produced, the fewer oil losses. The optimization of CPO production shows the effectiveness of fertilization which will increase the company income. By knowing the effectiveness of fertilization, we can determine the correct fertilizer dosage. The goal is that the costs incurred by the company for fertilizers can be minimized. Generally, the cost of fertilization is $40 \%-60 \%$ of the total maintenance cost or about $30 \%$ of the total production cost.

\section{CONCLUSIONS}

Fertilizer application in months with high rainfall and long dry season is less effective and efficient for nutrient availability. The productivity of FFB in the second semester after 6 months of fertilization has increased compared to the first semester. The dose of fertilizer that affects growth is 0.20 tonnes/ha. The effective application of fertilizers can increase the production of CPO and reduce the total maintenance cost of the oil palm company.

\section{REFERENCES}

Akinnifesi, F. K., Mhango, J., Sileshi, G., \& Chilanga, T. (2008). Early growth and survival of three miombo woodland indigenous fruit tree species under fertilizer, manure and dry-season irrigation in southern Malawi. Forest Ecology and Management, 255(3-4), 546-557. https://doi.org/10.1016/j.foreco.2007.09.025 
Ariyanti, M., Maxiselly, Y., Rosniawaty, S., Pertanian, F., \& Padjadjaran, U. (2019). Pertumbuhan Kelapa Sawit Belum Menghasilkan Dengan Pemberian Pupuk Organik Asal Pelepah Kelapa Sawit Dan Asam Humat the Growth of Immature Oil Palm With the Application of Oil Palm Midrib Organic Fertilizer and Humic Acid. 27(2), 71-82.

Ball, K. R., Baldock, J. A., Penfold, C., Power, S. A., Woodin, S. J., Smith, P., \& Pendall, E. (2020). Soil organic carbon and nitrogen pools are increased by mixed grass and legume cover crops in vineyard agroecosystems: Detecting short-term management effects using infrared $\begin{array}{lll}\text { spectroscopy. } & \text { Geoderma, } & 114619 .\end{array}$ https://doi.org/10.1016/j.geoderma.2020.114619

Boafo, D. K., Kraisornpornson, B., Panphon, S., Owusu, B. E., \& Amaniampong, P. N. (2020). Effect of organic soil amendments on soil quality in oil palm production. Applied Soil Ecology, 147(September), 103358. https://doi.org/10.1016/j.apsoil.2019.09.008

Chiamaka, O., Akin, O., Marthy, F., \& Oluranti, O. (2020). Data on the vegetative response of cowpea to fertilizer application on three selected benchmark soils of the Upper West region of Ghana. Data in Brief, 30, 105590. https://doi.org/10.1016/j.dib.2020.105590

Cui, N., Cai, M., Zhang, X., Abdelhafez, A. A., \& Zhou, L. (2020). Runoff loss of nitrogen and phosphorus from a rice paddy fi eld in the east of China: Effects of long-term chemical $\mathrm{N}$ fertilizer and organic manure applications. Global Ecology and Conservation, 22, e01011. https://doi.org/10.1016/j.gecco.2020.e01011

Darko, C., Yeboah, S., Amoah, A., Opoku, A., \& Berchie, J. N. (2020). Productivity of Sweet potato (Ipomoea batatas (L) Lam) as Influenced by Fertilizer Application in Different Agro-ecologies in Ghana. Scientific African, L, e00560. https://doi.org/10.1016/j.sciaf.2020.e00560

Devani, V. (2014). Analisis Kehilangan Minyak Pada Crude Palm Oil ( Cpo ) Dengan Menggunakan Metode Statistical Process Control. 155, 28-42.

Emmanuel, O. C., Akintola, O. A., Tetteh, F. M., \& Babalola, O. O. (2020). Data on the vegetative response of cowpea to fertilizer application on three selected benchmark soils of the Upper West region of Ghana. Data in Brief, 30, 105590. https://doi.org/10.1016/j.dib.2020.105590

Ginting, E. N., Rahutomo, S., \& Sutarta, E. S. (2018). Efisiensi Serapan Hara Beberapa Jenis Pupuk Pada Bibit Kelapa Sawit Nutrients Use Efficiency of Several Types of Fertilizers on the Oil Palm Seedling. 26(2), 79-90.

Moreno-Sader, K., Alarcón-Suesca, C., \& González-Delgado, A. D. (2020). Application of environmental and hazard assessment methodologies towards the sustainable production of crude palm oil in North-Colombia. Sustainable Chemistry and Pharmacy, 15(June 2019), 110. https://doi.org/10.1016/j.scp.2020.100221

Njoroge, S., Schut, A. G. T., Giller, K. E., \& Zingore, S. (2019). Learning from the soil 's memory: Tailoring of fertilizer application based on past manure applications increases fertilizer use e ffi ciency and crop productivity on Kenyan smallholder farms. European Journal of Agronomy, 105(February), 52-61. https://doi.org/10.1016/j.eja.2019.02.006

Otto, R., Pereira, G. L., Tenelli, S., Carvalho, J. L. N., Lavres, J., de Castro, S. A. Q., Lisboa, I. P., \& Sermarini, R. A. (2020). Planting legume cover crop as a strategy to replace synthetic N fertilizer applied for sugarcane production. Industrial Crops and Products, 156(June), 112853. https://doi.org/10.1016/j.indcrop.2020.112853

Rasool, G., Guo, X., Wang, Z., Ali, M. U., Chen, S., Zhang, S., Wu, Q., \& Ullah, M. S. (2020). Coupling fertigation and buried straw layer improves fertilizer use efficiency, fruit yield, and quality of greenhouse tomato. Agricultural Water Management, 239(April), 106239. https://doi.org/10.1016/j.agwat.2020.106239

Rodriguez, C., Carlsson, G., Englund, J., Flöhr, A., Pelzer, E., Jeu, M., Makowski, D., \& Steen, E. (2020). Grain legume-cereal intercropping enhances the use of soil-derived and biologically $f i$ xed nitrogen in temperate agroecosystems . A meta-analysis. 118(July 2019). https://doi.org/10.1016/j.eja.2020.126077

Setyawan, H., Rohmiyati, S. M., \& Purba, J. H. (2020). Application of Cow Manure, Urea and NPK Fertilizer Combination on the Growth of Palm Oil (Elaeis Guineensis Jacq) in Pre-Nursery. Agro Bali : Agricultural Journal, 3(1), 74-83. https://doi.org/10.37637/ab.v3i1.419

Siallagan, I., Sudrajat, \& Hariyadi. (2014). Optimasi Dosis Pupuk Organik dan NPK Majemuk pada Tanaman Kelapa Sawit Belum Menghasilkan Optimizing Rate of Organic and NPK Compound Fertilizers for Immature Oil Palm. Optimasi Dosis Pupuk Organik Dan NPK Majemuk Pada Tanaman Kelapa Sawit Belum Menghasilkan, 42(2), 166-172.

Tounkara, A., Clermont-Dauphin, C., Affholder, F., Ndiaye, S., Masse, D., \& Cournac, L. (2020). Inorganic fertilizer use efficiency of millet crop increased with organic fertilizer application in rainfed agriculture on smallholdings in central Senegal. Agriculture, Ecosystems and 
Environment, 294. https://doi.org/10.1016/j.agee.2020.106878

Tröster, M. F., Pahl, H., \& Sauer, J. (2019). Effects of application costs on fertilizer application strategy. Computers and Electronics in Agriculture, 167(September), 105033. https://doi.org/10.1016/j.compag.2019.105033

Wulandari, N., \& Hernawati, H. (2017). Fraksinasi Minyak Sawit Kasar dengan Pelarut Organik dalam Pembuatan Konsentrat Karotenoid Crude Palm Oil Fractination with Organic Solutions in Carotenoid Concentrate Production. 4(2), 83-91.

Youse, M., Shakrine, A., Ra, M., Abd, S., \& Azrad, S. (2020). South African Journal of Botany Introduction of current pollination techniques and factors affecting pollination effectiveness by Elaeidobius kamerunicus in oil palm plantations on regional and global scale : A review. 132, 171-179. https://doi.org/10.1016/j.sajb.2020.04.017

Zhang, M., Sun, D., Niu, Z., Yan, J., \& Zhou, X. (2020). Effects of combined organic / inorganic fertilizer application on growth, photosynthetic characteristics, yield and fruit quality of Actinidia chinesis cv 'Hongyang .' Global Ecology and Conservation, 22, e00997. https://doi.org/10.1016/j.gecco.2020.e00997 